Dhaka Univ. J. Sci. 60(2): 289-290, 2012 (July)

Short Communication

\title{
Estimation of Iron and Metronidazole Content from Respective Oral Dosage Forms Available in Local Market
}

\author{
Sadia Afrin Chanda, Tarikul Islam Tuhin, Tanvir Muslim and Md. Azizur Rahman* \\ Department of Chemistry, University of Dhaka, Dhaka-1000, Bangladesh \\ Received on 05. 10. 2011. Accepted for Publication on 01. 12. 2011.
}

Iron is an absolute requirement for most forms of life, including humans and most bacterial species. In humans, iron is an essential component of proteins involved in oxygen transport. Iron is essential to life, because of its unique ability to serve both as an electron donor and acceptor and for the regulation of cell growth and differentiation. Iron supplements are prescribed by doctors for medical reasons. Supplemental iron is available in two forms: ferrous and ferric $^{1}$. Metronidazole was introduced as an antiprotozoal agent but it is also active against anaerobic bacteria. It is effective in the therapy of pseudo membranous colitis and aclostridial infection. It is the most effective drug available for invasive amoebiasis involving the intestine or the liver. Metronidazole was found to have particularly high activity in vitro and in vivo against Tricomonas vaginalis and Enterobacter histolytica ${ }^{2}$.

Various types of oral dosage forms (tablets or capsules) of iron and metronidazole ${ }^{3}$, manufactured by different pharmaceutical companies, are available in local market. These dosage forms are taken by the people according to the prescription of the doctors. The content of the active ingredients in dosage forms are specified by the manufacturers, but in many cases the declared amounts of the active ingredients are not found to be present within the acceptable range. This is a report of estimation of iron content in different iron tablets or capsules by both titrimetric method and UV-spectrophotometric method, and estimation of metronidazole content in different metronidazole tablets only by UV-spectrophotometric method.
Collection of iron and metronidazole tablets: Iron tablets or capsules and metronidazole tablets of ten and seventeen companies, respectively were collected from local market. The brand names of different iron tablets or capsules, which were used for analysis, were Ferocit, Femitab, Ipec-plus, Hemofol-TR, Zif, Zeefol, Ferrolin-TR, Feofol-CI, Feona_Z and Alneed-plus. The brand names of metronidazole tablets were Remetrol, Metsina, Filmet, Nidazyl, Metro, Dirozyl, Metco, Biozyl, Metryl, Amodis, Amotrex, Flamyd, Klion, Metason, Metronid, U-Met and Albion. The iron tablets/capsules and metronidazole tablets were arbitrarily marked as $F_{1}$ to $F_{10}$ and $M_{1}$ to $M_{17}$, respectively for analytical purpose.

Preparation of sample: Ten tablets or capsules of a particular brand were weighed and average weight was recorded. Then tablets or capsules were crushed into powder using mortar and pestle. Amount of average weight which is equivalent of one tablet or capsule of crushed powder was used for analysis.

Estimation of iron content in the iron tablets and capsules by titrimetric method ${ }^{4}$ : For the analysis of iron tablets or capsules, powdered sample (average weight) was dissolved in $20 \mathrm{~mL}$ dilute sulphuric acid and this solution was diluted into volumetric flask $(100 \mathrm{~mL})$. The prepared solution $(10.0 \mathrm{~mL})$ was taken in a conical flask with syrupy sulphuric acid and phosphoric acid mixture (15 $\mathrm{mL}$ ). Estimation of iron content in different tablets was done by titrating with standard potassium dichromate in presence of diphenylamine indicator. The results are presented in Table-1. Each result is the average of six values.

Table. 1. Amount of iron(II) content in iron tablet or capsule estimated by titrimetric method and UVspectrophotometric method.

\begin{tabular}{|c|c|c|c|c|c|}
\hline \multirow[t]{2}{*}{ Sample code } & \multirow[t]{2}{*}{ Active ingredient } & \multirow{2}{*}{$\begin{array}{l}\text { Wt. of one } \\
\text { dosage form } \\
\text { (g) }\end{array}$} & \multirow{2}{*}{$\begin{array}{c}\text { Theoretical } \\
\text { amount of iron } \\
(\mathrm{mg})\end{array}$} & \multicolumn{2}{|c|}{ Amount of iron(II) (mg/tablet) } \\
\hline & & & & $\begin{array}{l}\text { Titrimetric } \\
\text { method }\end{array}$ & $\begin{array}{l}\text { UV-Spectrophotometric } \\
\text { method }\end{array}$ \\
\hline F1 & Ferrous fumarate $\mathrm{BP}^{\mathrm{a}}$ & 0.3310 & 65.74 & 59.27 & 39.47 \\
\hline F2 & Ferrous fumarate $\mathrm{BP}^{\mathrm{a}}$ & 0.3464 & 65.74 & 61.49 & 40.47 \\
\hline F3 & $\begin{array}{l}\text { Iron(III) hydroxide polymaltose } \\
\text { complex INN }\end{array}$ & 0.4501 & 47.0 & 50.54 & 42.52 \\
\hline F4 & Ferrous sulfate $\mathrm{BP}^{\mathrm{c}}$ & 0.4372 & 55.17 & 48.77 & 43.72 \\
\hline F5 & Dried ferrous sulfate $\mathrm{BP}^{\mathrm{c}}$ & 0.4650 & 55.17 & 52.42 & 40.95 \\
\hline F6 & Dried ferrous sulfate USP $^{c}$ & 0.4347 & 55.17 & 49.59 & 41.12 \\
\hline F7 & Dried ferrous sulfate $\mathrm{BP}^{\mathrm{c}}$ & 0.4838 & 55.17 & 49.29 & 43.35 \\
\hline F8 & $\begin{array}{l}\text { Elemental iron } \\
\text { (as carbonyl iron) }^{\mathrm{d}}\end{array}$ & 0.3356 & 50.0 & 46.05 & 33.31 \\
\hline F9 & Dried ferrous sulfate $^{c}$ & 0.4872 & 55.17 & 49.85 & 43.10 \\
\hline F10 & Dried ferrous sulfate $^{c}$ & 0.4567 & 55.17 & 52.05 & 43.47 \\
\hline
\end{tabular}

a: $200 \mathrm{mg}$; b: $188 \mathrm{mg}$; c: $150 \mathrm{mg}$; d: $50 \mathrm{mg}$. 
Estimation of iron content in the iron tablets and capsules by UV-spectrophotometric method ${ }^{5}$ : Standard Fe(II) solution of $0.1,0.2,0.5,1.0,2.0 \mathrm{ppm}$ was prepared by adding hydroxyl ammonium chloride solution $(1.0 \mathrm{~mL}), 1,10$-phenanthroline solution $(5.0 \mathrm{~mL})$ and sodium acetate solution $(8.0 \mathrm{~mL})$ in a volumetric flask $(100 \mathrm{~mL})$ to produce the red color of ferrous 1,10-phenanthroline. Each solution was diluted to exactly 100 $\mathrm{mL}$ and a blank solution was prepared for using as a reference. Absorption of each solution including blank was recorded at 510 $\mathrm{nm}$ using a UV-visible spectrophotometer (Shimadzu UV160A). The absorbances of the standard solutions were plotted against concentration to obtain a calibration curve. Accurately weighed powdered iron tablet or capsule $(0.2 \mathrm{~g})$ was dissolved in aqua-regia and diluted into $100 \mathrm{~mL}$. This solution was again diluted 10 times by taking $10.0 \mathrm{~mL}$ of this solution into another volumetric flask $(100 \mathrm{~mL})$. Hydroxyl ammonium chloride (1.0 $\mathrm{mL}), 1,10$-phenanthroline $(5.0 \mathrm{~mL})$ and sodium acetate solution $(8.0 \mathrm{~mL})$ were added to it. Finally volume was made up to the mark with distilled water. The absorbance of the sample solution was recorded at $510 \mathrm{~nm}$ using a UV-visible spectrophotometer. Using the calibration curve, the final concentration of iron (II) in the sample solution was estimated. The results are presented in Table-1. Each result is the average of six values.

Table-2. Amount of metronidazole content in metronidazole tablet estimated by UV-spectrophotometric method.

\begin{tabular}{|c|c|c|}
\hline $\begin{array}{c}\text { Sample } \\
\text { code }\end{array}$ & $\begin{array}{c}\text { Amount of } \\
\text { metronidazole found } \\
(\mathrm{mg})\end{array}$ & Potency (\%)* \\
\hline M1 & 410.00 & 102.25 \\
\hline M2 & 410.00 & 102.25 \\
\hline M3 & 404.00 & 101.00 \\
\hline M4 & 415.00 & 103.75 \\
\hline M5 & 400.00 & 100.00 \\
\hline M6 & 406.00 & 101.50 \\
\hline M7 & 401.50 & 104.25 \\
\hline M8 & 413.00 & 103.25 \\
\hline M9 & 409.00 & 102.25 \\
\hline M10 & 400.00 & 100.00 \\
\hline M11 & 498.00 & 99.60 \\
\hline M12 & 401.00 & 100.25 \\
\hline M13 & 409.00 & 102.25 \\
\hline M14 & 402.00 & 100.50 \\
\hline M15 & 405.00 & 101.25 \\
\hline M16 & 398.00 & 99.00 \\
\hline M17 & 380.00 & 95.00 \\
\hline
\end{tabular}

* Declared amount of active ingredient in each tablet was Metronidazole BP $400 \mathrm{mg}$

Estimation of metronidazole content in metronidazole tablets by UV-spectrophotometric method ${ }^{3}:$ A standard metrinidazole solution $(0.023 \mathrm{mg} / \mathrm{mL}$, Solution- 1$)$ was prepared by adding required amount of standard metronidazole into a volumetric flask $(100 \mathrm{~mL}) . \mathrm{HCl}$ solution $(0.1 \mathrm{M})$ was added to make to volume upto the mark. Absorbance of this solution was measured at $277 \mathrm{~nm}$ using a UV-visible spectrophotometer. This standard solution (Solution-1) was serially diluted to prepare 0.0023 , $0.0046,0.0069,0.0092,00115,0.0138,0.0161,0.0184$ and 0.0207 $\mathrm{mg} / \mathrm{mL}$ standard metronidazole solutions. The absorbance of each standard solution was measured at $277 \mathrm{~nm}$ using a UV-visible spectrophotometer. A calibration curve was prepared by plotting absorbance of the standard solutions against different concentrations. One powdered tablet (average weight) was dissolved in little amount of $\mathrm{HCl}(0.1 \mathrm{M})$. The solution was filtered. The volume of the filtrate was adjusted to $100 \mathrm{~mL}$ by adding $\mathrm{HCl}(0.1 \mathrm{M})$ using a $100 \mathrm{~mL}$ volumetric flask. This solution was again diluted to 200 times. The absorbance of this sample solution was recorded using a UV-visible spectrophotometer. Using the calibration curve, the final amount of metronidazole in the sample solution was estimated. The results are presented in Table-2. Each result is the average of six values. Theoretically, the amount of iron content in the sample F1 is 65.74 $\mathrm{mg}$. It was found to be $59.27 \mathrm{mg}$ by titrimetric method. On the other hand, the amount of iron content the sample F1 was found to be 39.47 by spectrophotometric method which is less than titrimetric method. Almost similar variation was found in other tablets or capsules. In titrimetric method, the estimated amount of iron(II) in each dosage form was found to be 5 to $12 \%$ less than that of the theoretical amount. This could be happened due to personal errors or tablet may contain lesser amount of iron content than the value declared by the manufacturers.

In UV-spectrophotometric method, the estimated amount of iron(II) in each dosage form was found to be 15 to $35 \%$ less than that of the theoretical amount. For metronidazole tablets, the estimated value varies from $380 \mathrm{mg}$ to $415 \mathrm{mg} /$ tablet which are very close to the declared value $(400 \mathrm{mg})$. For metronidazole tablets in UVspectroscopic method, the estimated amount of metronidazole in each dosage form was found to be 1 to $5 \%$ less than that of the declared amount. However, the variation of the values of active ingredient for both the iron or metronidazole tablets may be due to personal errors, but this finding gives the idea about the potency of the tablets used according to the prescription of the doctors.

Finally it can be concluded that the results obtained by this experimental procedure are less than the value stated by the manufacturer but the variation is within the acceptable range.

1. http://en.wikipedia.org/wiki/Iron_supplements; http://ods.od.nih.gov/factsheets/iron/

2. Eisenstein, B. I. and M. Schaechter, 2007. "DNA and Chromosome Mechanics". In Schaechter, M., N. C. Engleberg, V. J. DiRita and T. Dermody, Schaechter's mechanisms of microbial disease, Hagerstwon, M.D., Lippincott Williams \& Wilkins. p. 28.

3. Ahmed, F., A.K. Das, U.K. Karmakar, T. Khaleque and M.C. Shill, 2003. Quality of Marketed Metronidazole Preparations in Bangladesh- An Analytical Overview. Journal of Biological Sciences, 3(10), 940-950.

4. Vogel, A. I., 1961. A Textbook of Quantitative Inorganic Analysis, 3rd ed., Longmans, London.

5. Christian, G. D., 1986. Analytical Chemistry, $4^{\text {th }}$ Edition, John Wiley \& Sons, New York, 598-599. 
